\title{
Tissue Engineered Strategies for Skeletal Muscle Injury
}

\author{
Umile Giuseppe Longo, ${ }^{1,2}$ Mattia Loppini, ${ }^{1,2}$ Alessandra Berton, ${ }^{1,2}$ Filippo Spiezia,, ${ }^{1,2}$ \\ Nicola Maffulli, ${ }^{3}$ and Vincenzo Denaro ${ }^{1,2}$
}

\author{
${ }^{1}$ Department of Orthopaedic and Trauma Surgery, Campus Bio-Medico University, Via Alvaro del Portillo 200, \\ Trigoria, 00128 Rome, Italy \\ ${ }^{2}$ Centro Integrato di Ricerca (CIR) Campus Bio-Medico University, Via Alvaro del Portillo 21, 00128, Rome, Italy \\ ${ }^{3}$ Centre for Sports and Exercise Medicine, Barts and The London School of Medicine and Dentistry, Mile End Hospital, \\ 275 Bancroft Road, London E1 4DG, UK
}

Correspondence should be addressed to Umile Giuseppe Longo, g.longo@unicampus.it

Received 25 July 2011; Accepted 15 September 2011

Academic Editor: Wasim S. Khan

Copyright (C) 2012 Umile Giuseppe Longo et al. This is an open access article distributed under the Creative Commons Attribution License, which permits unrestricted use, distribution, and reproduction in any medium, provided the original work is properly cited.

\begin{abstract}
Skeletal muscle injuries are common in athletes, occurring with direct and indirect mechanisms and marked residual effects, such as severe long-term pain and physical disability. Current therapy consists of conservative management including RICE protocol (rest, ice, compression, and elevation), nonsteroidal anti-inflammatory drugs, and intramuscular corticosteroids. However, current management of muscle injuries often does not provide optimal restoration to preinjury status. New biological therapies, such as injection of platelet-rich plasma and stem-cell-based therapy, are appealing. Although some studies support PRP application in muscle-injury management, reasons for concern persist, and further research is required for a standardized and safe use of PRP in clinical practice. The role of stem cells needs to be confirmed, as studies are still limited and inconsistent. Further research is needed to identify mechanisms involved in muscle regeneration and in survival, proliferation, and differentiation of stem cells.
\end{abstract}

\section{Introduction}

Skeletal muscle injuries are common causes of severe longterm pain and physical disability, accounting for up to $55 \%$ of all sports injuries [1]. Contusions and strains are the most frequent muscle lesions, representing more than $90 \%$ of all sports-related injuries [2]. Mechanisms of muscle lesion can be divided into direct and indirect trauma. Direct injuries include lacerations and contusions, while indirect injuries include complete or incomplete muscle strains [3]. A muscle contusion takes place when a sudden, heavy compressive force is applied to the muscle [4]. A muscle strain occurs when an excessive tensile force is applied to the muscle leading to the overstraining of the myofibers up to a rupture near the myotendinous junction [5]. Muscle injuries can also result from a combination of these mechanisms. Finally, skeletal muscle can be damaged when compartment syndromes occur because of vascular and/or neurologic impairment $[3,6]$. Injuries can counter the beneficial effects of sports participation because of the residual effects. The associated morbidity, including painful contractures and muscle atrophy, can result in prolonged loss of activity and increased risk of recurrent injury [7]. In some instances, muscle injuries leads to inability of athletes to continue to practice sport.

Therefore, there is a need to improve skeletal muscle injury management. Conservative management is commonly accepted, according to the principle that "muscle injuries do heal conservatively." It follows the RICE protocol (rest, ice, compression, and elevation). Other therapies include the local application of heat and passive motion exercises. Drug therapy typically consists of nonsteroidal anti-inflammatory drugs (NSAIDs) and intramuscular corticosteroids.

Operative management is required only in selected patients, such as athletes with a large intramuscular hematoma, a complete strain of a muscle with no agonist muscles, or a partial strain when more than $50 \%$ of 
the muscle belly is damaged, or persisting extension pain $(>6$ months) in a previously injured muscle [8].

As current therapy does not seem to obtain complete restoration of preinjury status, new biological therapies could represent interesting and more effective strategies to manage muscle injuries. Biological therapies include cell therapy, tissue engineering, and the administration of growth factors with the goal of enhancing current therapies.

This paper provides an overview on current biological strategies for the management of patients with muscle injuries. The rationale behind these therapies and the best available evidence therapeutic options are reported.

\section{Growth Factors}

The healing process of the injured skeletal muscle is characterized by several bioactive molecules, including proinflammatory cytokines, transforming growth factorbeta (TGF- $\beta$ ) superfamily members, and angiogenic factors. For this reason, the growth factors and the cytokines represent a potential therapeutic option to improve the regeneration/repair process of injured skeletal muscles. These signaling molecules accelerate the regeneration of injured muscular tissue, providing a mitogenic stimulus activating myogenic precursor cells [9].

Each of these molecules shows specific biological activities. The transforming growth factor-beta (TGF- $\beta$ ) stimulates mesenchymal cell proliferation [10], promotes the proliferation of fibroblasts [11] and the biosynthesis of extracellular matrix, particularly type I collagen [12], regulates endothelial cell activity and angiogenesis [13], and inhibits satellite cell proliferation and differentiation [9]. Fibroblast growth factor (FGF) promotes proliferation of fibroblasts [14], stimulates satellite cells proliferation but inhibits their differentiation [15], and promotes the mitogenesis of mesenchymal cells [9]. Epidermal growth factor (EGF) stimulates fibroblasts migration and proliferation and regulates angiogenesis and extracellular matrix homeostasis [16]. The platelet-derived growth factor (PDGF) promotes the mitogenesis of mesenchymal cells and fibroblasts [17], induces proliferation of satellite cells, and inhibits the end stages of myoblast differentiation [18]. Vascular endothelial growth factor (VEGF) promotes endothelial cells mitogenesis and migration [19] and stimulates myoblast migration [20]. The neoangiogenesis plays a critical role in the healing process of muscle injuries. The new vessels sprout from the health tissue surrounding the lesion and provide the supply of oxygen, growth factor, and blood stem cell to enhance the regeneration process [21]. Thus, the restoration of vascular pattern in the injured area represents an early and necessary phase for regeneration and morphological and functional recovery of muscle tissue.

Based on the multitude of their biological effects, the clinical application of growth factors is affected by considerable side effects. An overexpression of growth factors such as TGF- $\beta$ and FGF has been related to inhibition of myoblasts differentiation and muscle fiber regeneration [15]. In addition, growth factors explain their stimulatory effect on both muscle cells and fibroblasts. Particularly, TGF- $\beta$ is one of the most important growth factors related to scar formation during healing, and it seems to drive the differentiation of myogenic cells into myofibroblastic cells. For this reason, muscle fiber regeneration and scartissue production can be considered two concomitant and competitive processes.

Also, the expression of growth factors is closely regulated by a large number of extracellular matrix (ECM) proteins, namely, the heparin sulfate proteoglycans and the small leucine-rich proteoglycans (SLRPs) $[22,23]$. Several growth factors need to bind the heparan sulphate proteoglycans and the SLRPs to provide their biological effects. Thus, the application of growth factors to promote healing of the damaged muscle tissue should include the administration of these specific ECM molecules.

To date, available data from experimental settings are contradictory. Some authors did not report any beneficial effects by the administration of FGF-2 [24] or overexpression of skeletal muscle specific isoform of IGF-1 (mIGF-1) at the injured region [25]. FGF-2, IGF-1, and nerve growth factors can promote muscle healing process, increasing resistance to tensile loading when compared to untreated muscles [26, 27]. Moreover, mouse myoblasts transduced with the IGF-I gene increase their growth rate and enhance the contractile force production of skeletal muscle substitutes consisting of hydrogel and IGF-I engineered myoblasts [28].

A combination of growth factors can be used to regulate the different process of regeneration of muscle tissue and scar tissue production. Thus, the application of IGF-I combined with TGF- $\beta$ allows to induce muscle regeneration, preventing the formation of a fibrous scar [29].

\section{Platelet-Rich Plasma (PRP)}

Platelet-rich plasma (PRP) therapy represents an interesting biological technique to provide tissue repair by inducing chemotactic, proliferative, and anabolic host cellular responses [30]. PRP is an autologous product consisting of bioactive agents derived from patients' own platelets [3133]. Usually, PRP is administered by local injection of the PRP solution or the application of a PRP gel at the time of surgery.

Given the large amount of biological agents required for tissue repair, PRP could be an ideal biological autologous product providing a balanced combination of mediators able to improve the healing process. In clinical practice, the blood clot at the site of injury is replaced with a smaller volume of PRP solution or gel. The increased concentration of platelet at the site of lesion provides a higher concentration of healing bioactive factors than in physiological conditions. To date, PRP has been proposed for management of tendon [34-36], ligament $[37,38]$, muscle [39], nerve $[40,41]$, bone $[42,43]$, and joint injuries $[44,45]$.

The effectiveness of autologous conditioned serum (ACS) has been compared with Traumeel/Actovegin in a nonrandomized nonblinded pilot study (level III) on muscle strain injuries in professional sportsmen [39]. The ACS 
was obtained from whole blood, and it contained bioactive proteins including interleukin- $1 \beta$ (IL- $1 \beta$ ), TNF- $\alpha$, IL-7, fibroblast growth factor-2 (FGF-2), IL-1Ra, HGF, PDGF$\mathrm{AB}, \mathrm{TGF} \beta 1$, and IGF-1. Traumeel is a homeopathic formulation containing both botanical and mineral ingredients in homeopathic concentrations. Actovegin is a deproteinized calf blood hemodialysate consisting of a physiological mix of amino acids. Although both treatments were safe, the ACS allowed to reduce the time to full recovery and the amount of edema and/or bleeding at MRI images.

These findings have been also confirmed in professional soccer players with muscle lesions varying for size and location [46]. Athletes were managed with activated pure PRP (P-PRP) injections. Full resumption of normal training activities was restored in half of the expected time compared to matched historical controls. The same leukocyte-free PRP preparation has been found effective to manage adductor longus strain in a professional bodybuilder [47].

ACS and PRP have been also evaluated in laboratory settings. ACS was compared with saline solution in a contusion injury model. ACS showed an earlier activation and/or recruitment of satellite cells, and an earlier fusion, with larger regenerating myofibers, compared with controls [48]. PRP increases proliferation of muscle cells, differentiation of satellite cells and synthesis of angiogenic factors in an in vitro setting [49]. PRP and leukocyte and platelet-rich plasma (L-PRP) have been also compared in a laboratorycontrolled study using a muscle strain rat model. The authors demonstrated that PRP is more effective than L-PRP in terms of myogenesis enhancement and contractile function [50].

Although preliminary data are encouraging, there are some reasons of concern about PRP treatment. First of all, PRP could induce a fibrotic healing response in muscle tissues, by increasing local concentration of TGF. According to experimental data, TGF seems to be able to induce fibrosis in cultured muscle tissue [9]. Moreover, the effectiveness of PRP could be affected by leukocytes within the injected solution, because their enzymes (proteases and acid hydrolases) can damage muscle tissue [51].

Finally, several devices and systems are available for PRP preparation. Therefore, PRP products applied in several studies consist of a basic mixture of grow factors including different concentration of each single agent. Moreover, level I studies performed with adequate outcome measures and follow-up assessment are lacking.

To date, no PRP formulation has solid evidence of effectiveness to heal muscle injuries. Pilot clinical studies indicate that PRP therapies may enhance muscle repair after strain or contusion. Moreover, laboratory data indicate the ability of several growth factors to enhance myogenesis. However, at present, there is no evidence to recommend or discourage the adoption of PRP in clinical practice. Further research is required to standardize formulations (number of platelets and/or leukocytes) and administration regimens, including volume of injection and timing of treatment, to optimize PRP application for management of muscle injuries.

\section{Cell Therapy}

In the last decade, regenerative medicine and tissue engineering increased their role in management of musculoskeletal diseases. Transplantation of stem cells has been considered a new strategy to repair injured tissues [52-64]. Different areas of application have been explored, such as articular cartilage [65-68], bone [69-72], ligament, and tendon [73-77]. The expectations for future therapeutic strategies are great.

The idea of cell therapies for muscle regeneration has been developed from the observation that skeletal muscle has regenerative capacity [78-80]. Several studies have investigated the role of stem cells in muscle healing, showing their direct participation in tissue regeneration and their influence in healing modulation $[12,81,82]$. However, severe muscle injuries are characterized by concomitant activation of regenerative activities of the satellite cells and profibrotic activities of fibroblasts $[83,84]$.

The specific expression pattern of growth factors in the region of injury determines the dominant cell type in the wound healing process [12]. High levels of TGF- $\beta 3$ are related to the activation of mesenchymal progenitor cells (MPCs) derived from traumatized muscle to promote wound healing after muscle injury [85]. On the other hand, high levels of TGF- $\beta 1$ are related to activation of fibroblasts to produce disorganized extracellular matrix leading to fibrosis in the muscle tissue $[81,82]$. The fibrotic tissue affects the ability of the satellite cells to repair the muscle tissue.

There are distinct subsets of myogenic cells. Muscle satellite cells (SCs) are localized under the basal lamina of muscle fibers [86]. They respond to regenerative stimuli by proliferating to form myoblasts which, in turn, differentiate and fuse in multinucleated myotubes [87, 88]. Their capability to renew and to produce differentiated progeny suggests that they are the adult stem-cell population of skeletal muscle [89]. They are also known as Pax7+ cells, based on their expression of the muscle-specific paired box (Pax) transcription factor Pax7 [90]. However, SCs consist of heterogeneous cell population, including Myf5+ cells (90\%) and Myf5- cells (10\%) [91]. The first of them are committed to the myogenic lineage because of expression of Myf5 which is an initiator of myogenic differentiation [92].

Other stem cells have been identified. They are both muscle specific, such as mesoangioblasts and pericytes, skeletal muscle precursors (SMPs), muscle stem cells (MuSCs), sidepopulation (SP) cells, and PW1-cells, and nonspecific, such as embryonic stem (ES) cell, amniotic fluid stem (AFS) cells, mesenchymal stem cells (MSCs), and mesenchymal cells from bone marrow [93]. They are able to contribute to muscle regeneration with different myogenic potential, but their potential is still undefined. Satellite cells seem to be sufficient for the regenerative need of damaged adult skeletal muscle in vivo [94]. The MSCs present a great migration potential toward the areas of induced muscle degeneration and undergo myogenic differentiation, providing regeneration of muscle tissue. The MSC transduction with transcription factors, such as MyoD, has been also investigated to enhance their potential of myogenic differentiation [95]. 
The properties of the stem cells in the muscle have been analyzed using animal models of muscle dysfunctions and injuries. Improved muscular structure has been observed in mice used as Duchene Muscular Dystrophy models treated with stem cells [96-98]. Better muscle regeneration has been obtained by the use of muscle-derived stem cells (MDSCs) in models of induced skeletal muscle injury [99]. MDSCs provide an improvement of muscle healing because of their ability to recruit capillaries and nerves into the injured region [99]. They are also able to differentiate directly into endothelial cells and cell types with neuronal characteristics [100]. For these reasons, muscle regeneration seems to be more powerful with MDSCs application compared with satellite cells application.

A model of hindlimb ischemia, analogous to exerciseinduced compartment syndrome, showed potential benefit of injections of marrow-derived stromal cells in term of perfusion, fibrosis development, and atrophy [101]. Results from ongoing studies on MDSCs implantation after musculoskeletal contusion are awaited [84].

The role of stem cells in musculoskeletal disease needs to be confirmed. Studies are still limited, and many questions are still unanswered. Several issues should be taken into account, such as safety and efficacy, immunogenicity, and biochemical factors involved in survival and differentiation of stem cells. Further research is needed to identify mechanisms involved in muscle regeneration to exactly understand the therapeutic potential of stem cells.

\section{Scaffolds}

Regenerative medicine is a multidisciplinary approach to produce living, functional substitutes for restoration, maintenance or improvement of the function of damaged tissue or organ. Tissue engineering is a specific approach included in regenerative medicine field. The tissue engineering consists of association of three main elements: cells, factors or stimuli, and biomaterials [102].

Musculoskeletal tissue engineering aims to obtain functional replacement of lost or damaged bone, cartilage, skeletal muscle, and tendon/ligament. In skeletal muscle injuries, tissue engineering represents a biological alternative for replacement of large tissue loss after severe damage.

Skeletal muscle tissue engineering could be performed by two different approaches: in vitro and in vivo. In in vitro tissue engineering, SCs from adult skeletal muscle are expanded and seeded on a 3D scaffold to produce a cell-biomaterial construct. After the differentiation of stem cells, the neotissue graft could be transplanted in the injured region. In in vivo tissue engineering, the isolated SCs are charged on a 3D scaffold carrier and promptly transplanted. Thus, the delivery of stem cells in the muscle lesion is obtained [93].

Efficient skeletal muscle regeneration is strongly related with features of biomaterials used to fabricate scaffold and with the regenerative potential of cells used for scaffold seeding. The source of cells used for scaffold seeding should be chosen based on the features of the damaged tissue. Cells can be autologous or allogeneic, including also stem cells where it is required.
The scaffold is a 3D-structure able to mimic the anatomical and biomechanical properties of the native tissue. The scaffold for muscle tissue engineering should be able to flex and stretch [103]. Moreover, they should be able to promote the alignment of myoblasts the assembly of myotubes. Nanostructured scaffolds are more efficient in promoting myotube assembly than microstructured scaffolds [104].

The biomaterials used to fabricate scaffold can be natural (like collagen) or synthetic (e.g., ceramics, polymers of lactic, and glycolic acid) and soluble or insoluble. Scaffold must have biocompatibility and biodegradability properties [105]. Biocompatibility is essential to prevent toxicity and immunogenicity biomaterial-related inducing the immuneresponse in the host muscle. Biodegradability allows gradual substitution of the scaffold by the newly formed muscle tissue. Moreover, the scaffold should integrate molecules or cells, providing a controlled delivery of growth factors, cytokines, plasmids, drugs, or other anabolic stimuli [106109]. In skeletal muscle tissue engineering, biomaterials should support the myogenic process, providing a microenvironment which allows cell survival, proliferation and/or differentiation to repair, and/or regenerate the damaged tissue.

Both synthetic and natural scaffolds have been investigated for tissue engineering approaches to muscle regeneration. The polylactic-co-glycolic acid (PGA) is a synthetic biodegradable biomaterial showing appropriate rigidity and connection, appropriate for muscle tissue engineering. Constructs of myoblasts and polyglycolic acid meshes have been evaluated in a muscle regeneration rat model. Regenerate tissue-like structures have been found with aligned myoblasts along strands of polymer fibers. The PGA scaffold allowed the alignment of myoblasts and the assembly of myotubes, reproducing the organization of muscle fibres [110].

In the field of natural biodegradable biomaterials, different 3D scaffolds have been developed. Collagen scaffolds with parallel oriented pores have been used to reproduce the three-dimensional organization of skeletal muscle [111]. Permanent myogenic cells were infiltrated in these scaffolds and were cultured to induce their proliferation and differentiation [111]. The collagen scaffold with oriented pore structure showed the ability to induce skeletal muscle-like tissue regeneration with aligned multinucleated myotubes according to the orientation of pore structure [111]. In addition, cell-scaffold constructs were able to support mechanical forces generated in muscle tissue [111]. These results have been also found in an in vitro study in which a multilayered cultures of rat neonatal satellite cells in collagen 3D scaffolds were performed [112].

Fibrin is another natural biodegradable 3D scaffold used to obtain muscle regeneration. Three-dimensional fibrin matrix has been used as carrier to inject myoblasts in the injured muscle region of a rat model. The fibrin carrier induced no inflammatory reaction and allowed integration of myoblasts into host muscle fibers [113]. The fibrin matrix also allows to produce strained fibrin gel by applying continuous tensile strain to fibrin scaffold. The morphological features of strained fibrin gels induce the alignment of seeded myoblasts. Moreover, the aligned cells are parallel to 
the direction of the strain reproducing the organization of skeletal muscle tissue [114]. The fibrin matrix also allows the differentiation of myoblasts, cultured in a three-dimensional pattern, under electrical stimulation [115]. Finally, fibrin scaffolds have been also combined with adult human cells to regenerate muscle after large tissue loss in a mouse model with large defect of tibialis anterior muscle. Constructs of fibrin microthreads and adult human cells were used, showing the role of constructs in host tissue regeneration by forming skeletal muscle fibers, connective tissue, and PAX7 positive cells [116].

Another type of natural scaffold is a hyaluronan-based hydrogel that has been used to perform the delivery of either SCs or MPCs in a mice model. The construct SC-hydrogel showed more enhancement of regeneration process with a higher number of new myofibers than MPC-hydrogel or hydrogel alone. In the muscle receiving the SCs, there was a functional SC niche associated with neural and vascular networks [117].

The acellular muscle ECM has been also investigated in muscle tissue-engineering field. The acellular muscle scaffold was derived from the extensor digitorum longus muscle, and was injected with myoblasts. The constructs allowed cell survival and proliferation and showed longitudinal contractile force on electrical stimulation [118].

Each type of scaffold shows specific proprieties and peculiar advantages. The final goal of scaffold fabrication consists of promoting the proliferation of muscle stem cells, their differentiation, and parallel alignment to obtain a new skeletal muscle-like tissue. The application of scaffold for regeneration of muscle tissue could represents an interesting approach particularly in the major trauma with large loss of tissue. In the majority of muscle injuries, the role of scaffold remains unclear and maybe not as important as in bone or cartilage regeneration. In fact, the skeletal muscle is characterized by different layer of connective tissue, such as endomysium, perimysium, and epimysium, which seems to be able to drive the regeneration of new muscle fibers without the need of scaffold. Further studies are required to identify the best scaffold for skeletal muscle tissue engineering. However, the combination of available techniques could represent the right way to fabricate the ideal scaffold.

\section{Conclusion}

Skeletal muscle injuries are the most common injury in sport, occurring with direct and indirect mechanisms. Their effective management is a challenging issue in orthopaedic sport medicine because of the residual effects, such as severe long-term pain and physical disability. Skeletal muscle injuries cause time loss of activity and increased risk of recurrent injury. For these reasons, they constitute a health problem for athletes and an economic problem for clubs and sponsors.

In most of the instances, current therapy consists of conservative management including RICE protocol and administration of NSAIDs or intramuscular corticosteroids. However, current management of muscle injuries does not often provide an optimal restore of preinjury status because of the fibrosis which occurs during the repair process of injured muscle. Experimental studies highlight the biological bases of muscle healing after contusion, strain, or laceration injury. This provides the rationale basis for new biological therapies, such as PRP and growth factors, cellbased therapy and tissue engineering. Biological strategies may well be more favourable to healing. Although PRP application is encouraged, reasons for concern persist in its use for muscle injury management, and its mechanism of action remains uncertain. Further research is required to allow a standardized and safety use of this product in clinical practice. Cell-based strategies have been investigated only in limited and inconsistent studies. The role of stem cells needs to be confirmed. Further research is required to identify mechanisms involved in muscle regeneration and in survival, proliferation, and differentiation of stem cells. Skeletal muscle tissue engineering represents a biological alternative for replacement of large tissue loss after severe damage, based on combination of adult or embryonic stem cells, factors or stimuli, and biomaterials. However, further studies are required to identify the best biomaterial to fabricate the ideal scaffold, the best cell source for scaffold seeding, and the role of growth factors and other stimuli used to functionalize the scaffold.

\section{References}

[1] J. M. Beiner and P. Jokl, "Muscle contusion injuries: current treatment options," The Journal of the American Academy of Orthopaedic Surgeons, vol. 9, no. 4, pp. 227-237, 2001.

[2] T. A. H. Järvinen, T. L. N. Järvinen, M. Kääriäinen et al., "Muscle injuries: optimising recovery," Best Practice and Research: Clinical Rheumatology, vol. 21, no. 2, pp. 317-331, 2007.

[3] T. A. H. Järvinen, T. L. N. Järvinen, M. Kääriäinen, H. Kalimo, and M. Järvinen, "Muscle injuries: biology and treatment," American Journal of Sports Medicine, vol. 33, no. 5, pp. 745-764, 2005.

[4] J. J. Crisco, P. Jokl, G. T. Heinen, M. D. Connell, and M. M. Panjabi, "A muscle contusion injury model. Biomechanics, physiology, and histology," American Journal of Sports Medicine, vol. 22, no. 5, pp. 702-710, 1994.

[5] W. E. Garrett, "Muscle strain injuries," American Journal of Sports Medicine, vol. 24, pp. S2-S8, 1996.

[6] J. L. Howard, N. G. H. Mohtadi, and J. P. Wiley, "Evaluation of outcomes in patients following surgical treatment of chronic exertional compartment syndrome in the leg," Clinical Journal of Sport Medicine, vol. 10, no. 3, pp. 176-184, 2000.

[7] J. Huard, Y. Li, and F. H. Fu, "Muscle injuries and repair: current trends in research," The Journal of Bone and Joint Surgery, vol. 84, pp. 822-832, 2002.

[8] T. A. H. Järvinen, T. L. N. Järvinen, M. Kääriäinen, H. Kalimo, and M. Järvinen, "Muscle injuries: biology and treatment," American Journal of Sports Medicine, vol. 33, no. 5, pp. 745-764, 2005.

[9] I. Husmann, L. Soulet, J. Gautron, I. Martelly, and D. Barritault, "Growth factors in skeletal muscle regeneration," Cytokine and Growth Factor Reviews, vol. 7, no. 3, pp. 249258, 1996. 
[10] A. B. Roberts, N. S. Roche, and M. B. Sporn, "Selective inhibition of the anchorage-independent growth of myctransfected fibroblasts by retinoic acid," Nature, vol. 315, no. 6016, pp. 237-239, 1985.

[11] A. B. Roberts, M. A. Anzano, and L. M. Wakefield, "Type $\beta$ transforming growth factor: a bifunctional regulator of cellular growth," Proceedings of the National Academy of Sciences of the United States of America, vol. 82, no. 1, pp. 119123, 1985.

[12] Y. Li, W. Foster, B. M. Deasy et al., "Transforming growth Factor- $\beta 1$ induces the differentiation of myogenic cells into fibrotic cells in injured skeletal muscle: a key event in muscle fibrogenesis," American Journal of Pathology, vol. 164, no. 3, pp. 1007-1019, 2004.

[13] M. B. Sporn, A. B. Roberts, L. M. Wakefield, and R. K. Assoian, "Transforming growth factor factor- $\beta$ : biological function and chemical structure," Science, vol. 233, no. 4763, pp. 532-534, 1986.

[14] T. Floss, H. H. Arnold, and T. Braun, "A role for FGF-6 in skeletal muscle regeneration," Genes and Development, vol. 11, no. 16, pp. 2040-2051, 1997.

[15] R. E. Allen and L. K. Boxhorn, "Regulation of skeletal muscle satellite cell proliferation and differentiation by transforming growth factor-beta, insulin-like growth factor I, and fibroblast growth factor," Journal of Cellular Physiology, vol. 138, no. 2, pp. 311-315, 1989.

[16] B. M. Deasy, Z. Qu-Peterson, J. S. Greenberger, and J. Huard, "Mechanisms of muscle stem cell expansion with cytokines," Stem Cells, vol. 20, no. 1, pp. 50-60, 2002.

[17] L. T. Williams, "Signal transduction by the platelet-derived growth factor receptor," Science, vol. 243, no. 4898, pp. 1564 1570, 1989.

[18] R. Ross, E. W. Raines, and D. F. Bowen-Pope, "The biology of platelet-derived growth factor," Cell, vol. 46, no. 2, pp. 155 $169,1986$.

[19] N. Ferrara, H. P. Gerber, and J. LeCouter, "The biology of VEGF and its receptors," Nature Medicine, vol. 9, no. 6, pp. 669-676, 2003.

[20] A. Germani, A. Di Carlo, A. Mangoni et al., "Vascular endothelial growth factor modulates skeletal myoblast function," American Journal of Pathology, vol. 163, no. 4, pp. 1417-1428, 2003.

[21] M. Jarvinen, "Healing of a crush injury in rat striated muscle. III. A micro angiographical study of the effect of early mobilization and immobilization on capillary ingrowth," Acta Pathologica et Microbiologica Scandinavica Section A, vol. 84, no. 1, pp. 85-94, 1976.

[22] J. C. Casar, C. Cabello-Verrugio, H. Olguin, R. Aldunate, N. C. Inestrosa, and E. Brandan, "Heparan sulfate proteoglycans are increased during skeletal muscle regeneration: requirement of syndecan-3 for successful fiber formation," Journal of Cell Science, vol. 117, no. 1, pp. 73-84, 2004.

[23] J. Villena and E. Brandan, "Dermatan sulfate exerts an enhanced growth factor response on skeletal muscle satellite cell proliferation and migration," Journal of Cellular Physiology, vol. 198, no. 2, pp. 169-178, 2004.

[24] C. A. Mitchell, J. K. McGeachie, and M. D. Grounds, "The exogenous administration of basic fibroblast growth factor to regenerating skeletal muscle in mice does not enhance the process of regeneration," Growth Factors, vol. 13, no. 1-2, pp. 37-55, 1996.

[25] T. Shavlakadze, M. Davies, J. D. White, and M. D. Grounds, "Early regeneration of whole skeletal muscle grafts is unaffected by overexpression of IGF-1 in MLC/mIGF-1 trans- genic mice," Journal of Histochemistry and Cytochemistry, vol. 52, no. 7, pp. 873-883, 2004.

[26] C. Kasemkijwattana, J. Menetrey, P. Bosch et al., "Use of growth factors to improve muscle healing after strain injury," Clinical Orthopaedics and Related Research, no. 370, pp. 272285, 2000.

[27] J. Menetrey, C. Kasemkijwattana, C. S. Day et al., "Growth factors improve muscle healing in vivo," Journal of Bone and Joint Surgery. Series B, vol. 82, no. 1, pp. 131-137, 2000.

[28] M. Sato, A. Ito, Y. Kawabe, E. Nagamori, and M. Kamihira, "Enhanced contractile force generation by artificial skeletal muscle tissues using IGF-I gene-engineered myoblast cells," Journal of Bioscience and Bioengineering, vol. 112, no. 3, pp. 273-278, 2011.

[29] K. Sato, Y. Li, W. Foster et al., "Improvement of muscle healing through enhancement of muscle regeneration and prevention of fibrosis," Muscle and Nerve, vol. 28, no. 3, pp. 365-372, 2003.

[30] E. Anitua, M. Sánchez, A. T. Nurden, P. Nurden, G. Orive, and I. Andía, "New insights into and novel applications for platelet-rich fibrin therapies," Trends in Biotechnology, vol. 24, no. 5, pp. 227-234, 2006.

[31] F. Forriol, U. G. Longo, C. Concejo, P. Ripalda, N. Maffulli, and V. Denaro, "Platelet-rich plasma, rhOP-1 (rhBMP-7) and frozen rib allograft for the reconstruction of bony mandibular defects in sheep. A pilot experimental study," Injury, vol. 40, pp. S44-S49, 2009.

[32] I. Andia, M. Sanchez, and N. Maffulli, "Tendon healing and platelet-rich plasma therapies," Expert Opinion on Biological Therapy, vol. 10, no. 10, pp. 1415-1426, 2010.

[33] I. Andia, M. Sánchez, and N. Maffulli, "Platelet rich plasma therapies for sports muscle injuries: any evidence behind clinical practice?" Expert Opinion on Biological Therapy, vol. 11, no. 4, pp. 509-518, 2011.

[34] M. Sánchez, E. Anitua, J. Azofra, I. Andía, S. Padilla, and I. Mujika, "Comparison of surgically repaired Achilles tendon tears using platelet-rich fibrin matrices," American Journal of Sports Medicine, vol. 35, no. 2, pp. 245-251, 2007.

[35] G. Filardo, E. Kon, S. Della Villa, F. Vincentelli, P. M. Fornasari, and M. Marcacci, "Use of platelet-rich plasma for the treatment of refractory jumper's knee," International Orthopaedics, vol. 34, no. 6, pp. 909-915, 2010.

[36] J. C. Peerbooms, J. Sluimer, D. J. Bruijn, and T. Gosens, "Positive effect of an autologous platelet concentrate in lateral epicondylitis in a double-blind randomized controlled trial: platelet-rich plasma versus corticosteroid injection with a 1year follow-up," American Journal of Sports Medicine, vol. 38, no. 2, pp. 255-262, 2010.

[37] J. R. Nin, G. M. Gasque, A. V. Azcárate, J. D. Beola, and M. H. Gonzalez, "Has platelet-rich plasma any role in anterior cruciate ligament allograft healing?" Arthroscopy, vol. 25, no. 11, pp. 1206-1213, 2009.

[38] M. Sánchez, E. Anitua, J. Azofra, R. Prado, F. Muruzabal, and I. Andia, "Ligamentization of tendon grafts treated with an endogenous preparation rich in growth factors: gross morphology and histology," Arthroscopy, vol. 26, no. 4, pp. 470-480, 2010.

[39] T. Wright-Carpenter, P. Klein, P. Schäferhoff, H. J. Appell, L. M. Mir, and P. Wehling, "Treatment of muscle injuries by local administration of autologous conditioned serum: a pilot study on sportsmen with muscle strains," International Journal of Sports Medicine, vol. 25, no. 8, pp. 588-593, 2004.

[40] W. Yu, J. Wang, and J. Yin, "Platelet-rich plasma: a promising product for treatment of peripheral nerve regeneration after 
nerve injury," International Journal of Neuroscience, vol. 121, no. 4, pp. 176-180, 2011.

[41] H. H. Cho, S. Jang, S. C. Lee et al., "Effect of neuralinduced mesenchymal stem cells and platelet-rich plasma on facial nerve regeneration in an acute nerve injury model," Laryngoscope, vol. 120, no. 5, pp. 907-913, 2010.

[42] M. Latalski, Y. A. Elbatrawy, A. M. Thabet, A. Gregosiewicz, T. Raganowicz, and M. Fatyga, "Enhancing bone healing during distraction osteogenesis with platelet-rich plasma," Injury, vol. 42, no. 8, pp. 821-824, 2011.

[43] S. R. Kanthan, G. Kavitha, S. Addi, D. S.K. Choon, and T. Kamarul, "Platelet-rich plasma (PRP) enhances bone healing in non-united critical-sized defects: a preliminary study involving rabbit models," Injury, vol. 42, no. 8, pp. 782-789, 2011.

[44] M. Sánchez, E. Anitua, J. Azofra, J. J. Aguirre, and I. Andia, "Intra-articular injection of an autologous preparation rich in growth factors for the treatment of knee OA: a retrospective cohort study," Clinical and Experimental Rheumatology, vol. 26, no. 5, pp. 910-913, 2008.

[45] E. Kon, R. Buda, G. Filardo et al., "Platelet-rich plasma: intra-articular knee injections produced favorable results on degenerative cartilage lesions," Knee Surgery, Sports Traumatology, Arthroscopy, vol. 18, no. 4, pp. 472-479, 2010.

[46] W. L. Loo, D. Y. H. Lee, and M. Y. H. Soon, "Plasma rich in growth factors to treat adductor longus tear," Annals of the Academy of Medicine Singapore, vol. 38, no. 8, pp. 733-734, 2009.

[47] W. L. Loo, D. Y. H. Lee, and M. Y. H. Soon, "Plasma rich in growth factors to treat adductor longus tear," Annals of the Academy of Medicine Singapore, vol. 38, no. 8, pp. 733-734, 2009.

[48] T. Wright-Carpenter, P. Opolon, H. J. Appell, H. Meijer, P. Wehling, and L. M. Mir, "Treatment of muscle injuries by local administration of autologous conditioned serum: animal experiments using a muscle contusion model," International Journal of Sports Medicine, vol. 25, no. 8, pp. 582587, 2004.

[49] J. Alsousou, M. Thompson, P. Hulley, A. Noble, and K. Willett, "The biology of platelet-rich plasma and its application in trauma and orthopaedic surgery: a review of the literature," Journal of Bone and Joint Surgery. Series B, vol. 91, no. 8, pp. 987-996, 2009.

[50] B. H. Hamilton and T. M. Best, "Platelet-enriched plasma and muscle strain injuries: challenges imposed by the burden of proof," Clinical Journal of Sport Medicine, vol. 21, no. 1, pp. 31-36, 2011.

[51] J. W. Hammond, R. Y. Hinton, L. A. Curl, J. M. Muriel, and R. M. Lovering, "Use of autologous platelet-rich plasma to treat muscle strain injuries," American Journal of Sports Medicine, vol. 37, no. 6, pp. 1135-1142, 2009.

[52] E. A. Nauman and B. Deorosan, "The role of glucose, serum, and three-dimensional cell culture on the metabolism of bone marrow-derived mesenchymal stem cells," Stem Cells International, vol. 2011, Article ID 429187, 12 pages, 2011.

[53] S. Gavrilov, D. Marolt, N. C. Douglas et al., "Derivation of two new human embryonic stem cell lines from nonviable human embryos," Stem Cells International, vol. 2011, Article ID 765378, 9 pages, 2011.

[54] J. M. Gimble, B. A. Bunnell, L. Casteilla, J. S. Jung, and K. Yoshimura, "Phases I-III clinical trials using adult stem cells," Stem Cells International, vol. 2010, Article ID 604713, 2 pages, 2010.
[55] I. I. Katkov, N. G. Kan, F. Cimadamore, B. Nelson, E. Y. Snyder, and A. V. Terskikh, "DMSO-free programmed cryopreservation of fully dissociated and adherent human induced pluripotent stem cells," Stem Cells International, vol. 2011, Article ID 981606, 8 pages, 2011.

[56] C. Kelly, C. C. S. Flatt, and N. H. McClenaghan, "Stem cellbased approaches for the treatment of diabetes," Stem Cells International, vol. 2011, Article ID 424986, 8 pages, 2011.

[57] S.-J. Lu and E. A. Kimbrel, "Potential clinical applications for human pluripotent stem cell-derived blood components," Stem Cells International, vol. 2011, Article ID 273076, 11 pages, 2011.

[58] E Mansilla, V Díaz Aquino, D Zambón et al., "Could metabolic syndrome, lipodystrophy, and aging be mesenchymal stem cell exhaustion syndromes?" Stem Cells International, vol. 2011, Article ID 943216, 10 pages, 2011.

[59] R. T. Mitsuyasu, J. A. Zack, J. L. Macpherson, and G. P. Symonds, "Phase I/II clinical trials using gene-modified adult hematopoietic stem cells for HIV: lessons learnt," Stem Cells International, vol. 2011, Article ID 393698, 8 pages, 2011.

[60] H. Narimatsu, "Immune reactions following cord blood transplantations in adults," Stem Cells International, vol. 2011, Article ID 607569, 6 pages, 2011.

[61] A. D. Petropoulou and V. Rocha, "Risk factors and options to improve engraftment in unrelated cord blood transplantation," Stem Cells International, vol. 2011, Article ID 610514, 8 pages, 2011.

[62] C. Tekkatte, G. P. Gunasingh, K. M. Cherian, and K. Sankaranarayanan, "“Humanized” stem cell culture techniques: the animal serum controversy," Stem Cells International, vol. 2011, Article ID 504723, 14 pages, 2011.

[63] C. M. Teven, X. Liu, N. Hu et al., "Epigenetic regulation of mesenchymal stem cells: a focus on osteogenic and adipogenic differentiation," Stem Cells International, vol. 2011, Article ID 201371, 18 pages, 2011.

[64] T. J. Wyatt, S. L. Rossi, M. M. Siegenthaler et al., "Human motor neuron progenitor transplantation leads to endogenous neuronal sparing in 3 models of motor neuron loss," Stem Cells International, vol. 2011, Article ID 207231, 11 pages, 2011.

[65] F. H. Chen, K. T. Rousche, and R. S. Tuan, "Technology insight: adult stem cells in cartilage regeneration and tissue engineering," Nature Clinical Practice Rheumatology, vol. 2, no. 7, pp. 373-382, 2006.

[66] T. Matsumoto, S. Kubo, L. B. Meszaros et al., "The influence of sex on the chondrogenic potential of muscle-derived stem cells implications for cartilage regeneration and repair," Arthritis and Rheumatism, vol. 58, no. 12, pp. 3809-3819, 2008.

[67] R. Kuroda, A. Usas, S. Kubo et al., "Cartilage repair using bone morphogenetic protein 4 and muscle-derived stem cells," Arthritis and Rheumatism, vol. 54, no. 2, pp. 433-442, 2006.

[68] W. M. Jackson, A. B. Aragon, F. Djouad et al., "Mesenchymal progenitor cells derived from traumatized human muscle," Journal of Tissue Engineering and Regenerative Medicine, vol. 3, no. 2, pp. 129-138, 2009.

[69] J. Y. Lee, Z. Qu-Petersen, B. Cao et al., "Clonal isolation of muscle-derived cells capable of enhancing muscle regeneration and bone healing," Journal of Cell Biology, vol. 150, no. 5, pp. 1085-1099, 2000.

[70] H. Peng, V. Wright, A. Usas et al., "Synergistic enhancement of bone formation and healing by stem cell-expressed VEGF 
and bone morphogenetic protein-4," Journal of Clinical Investigation, vol. 110, no. 6, pp. 751-759, 2002.

[71] V. J. Wright, H. Peng, A. Usas et al., "BMP4-expressing muscle-derived stem cells differentiate into osteogenic lineage and improve bone healing in immunocompetent mice," Molecular Therapy, vol. 6, no. 2, pp. 169-178, 2002.

[72] J. Huard, A. Usas, A. M. Ho, G. M. Cooper, A. Olshanski, and H. Peng, "Bone regeneration mediated by BMP4-expressing muscle-derived stem cells is affected by delivery system," Tissue Engineering. Part A, vol. 15, no. 2, pp. 285-293, 2009.

[73] Z. Ge, J. C. H. Goh, and E. H. Lee, "Selection of cell source for ligament tissue engineering," Cell Transplantation, vol. 14, no. 8, pp. 573-583, 2005.

[74] K. A. Hildebrand, F. Jia, and S. L. Y. Woo, "Response of donor and recipient cells after transplantation of cells to the ligament and tendon," Microscopy Research and Technique, vol. 58, no. 1, pp. 34-38, 2002.

[75] F. Van Eijk, D. B. F. Saris, J. Riesle et al., "Tissue engineering of ligaments: a comparison of bone marrow stromal cells, anterior cruciate ligament, and skin fibroblasts as cell source," Tissue Engineering, vol. 10, no. 5-6, pp. 893-903, 2004.

[76] N. Watanabe, S. L. Y. Woo, C. Papageorgiou, C. Celechovsky, and S. Takai, "Fate of donor bone marrow cells in medial collateral ligament after simulated autologous transplantation," Microscopy Research and Technique, vol. 58, no. 1, pp. 39-44, 2002.

[77] C. K. Kuo and R. S. Tuan, "Mechanoactive tenogenic differentiation of human mesenchymal stem cells," Tissue Engineering. Part A, vol. 14, no. 10, pp. 1615-1627, 2008.

[78] J. N. Walton and R. D. Adams, "The response of the normal, the denervated and the dystrophic muscle-cell to injury," The Journal of Pathology and Bacteriology, vol. 72, no. 1, pp. 273298, 1956.

[79] W. E. LeGros Clark, "An experimental study of regeneration of mammalian striped muscle," Journal of Anatomy, vol. 80, pp. 24-36, 1946.

[80] S. Bintliff and B. E. Walker, "Radioautographic study of skeletal muscle regeneration," American Journal of Anatomy, vol. 106, no. 3, pp. 233-245, 1960.

[81] A. J. Cowin, T. M. Holmes, P. Brosnan, and M. W. J. Ferguson, "Expression of TGF- $\beta$ and its receptors in murine fetal and adult dermal wounds," European Journal of Dermatology, vol. 11, no. 5, pp. 424-431, 2001.

[82] L. Lu, A. S. Saulis, W. R. Liu et al., "The temporal effects of anti-TGF- $\beta 1,2$, and 3 monoclonal antibody on wound healing and hypertrophic scar formation," Journal of the American College of Surgeons, vol. 201, no. 3, pp. 391-397, 2005.

[83] Y. Li and J. Huard, "Differentiation of muscle-derived cells into myofibroblasts in injured skeletal muscle," American Journal of Pathology, vol. 161, no. 3, pp. 895-907, 2002.

[84] A. J. Quintero, V. J. Wright, F. H. Fu, and J. Huard, "Stem cells for the treatment of skeletal muscle injury," Clinics in Sports Medicine, vol. 28, no. 1, pp. 1-11, 2009.

[85] W. M. Jackson, L. J. Nesti, and R. S. Tuan, "Potential therapeutic applications of muscle-derived mesenchymal stem and progenitor cells," Expert Opinion on Biological Therapy, vol. 10, no. 4, pp. 505-517, 2010.

[86] A. Mauro, "Satellite cell of skeletal muscle fibers," The Journal of Biophysical and Biochemical Cytology, vol. 9, pp. 493-495, 1961.

[87] J. E. Morgan and T. A. Partridge, "Muscle satellite cells," International Journal of Biochemistry and Cell Biology, vol. 35, no. 8, pp. 1151-1156, 2003.
[88] J. C. Sloper and T. A. Partridge, "Skeletal muscle: regeneration and transplantation studies," British Medical Bulletin, vol. 36, no. 2, pp. 153-158, 1980.

[89] A. J. Wagers and I. M. Conboy, "Cellular and molecular signatures of muscle regeneration: current concepts and controversies in adult myogenesis," Cell, vol. 122, no. 5, pp. 659-667, 2005.

[90] P. Seale, L. A. Sabourin, A. Girgis-Gabardo, A. Mansouri, P. Gruss, and M. A. Rudnicki, "Pax7 is required for the specification of myogenic satellite cells," Cell, vol. 102, no. 6, pp. 777-786, 2000.

[91] S. Kuang, K. Kuroda, F. Le Grand, and M. A. Rudnicki, "Asymmetric self-renewal and commitment of satellite stem cells in muscle," Cell, vol. 129, no. 5, pp. 999-1010, 2007.

[92] H. Weintraub, R. Davis, S. Tapscott et al., "The myoD gene family: nodal point during specification of the muscle cell lineage," Science, vol. 251, no. 4995, pp. 761-766, 1991.

[93] C. A. Rossi, M. Pozzobon, and P. De Coppi, "Advances in musculoskeletal tissue engineering: moving towards therapy," Organogenesis, vol. 6, no. 3, pp. 167-172, 2010.

[94] C. A. Collins, I. Olsen, P. S. Zammit et al., "Stem cell function, self-renewal, and behavioral heterogeneity of cells from the adult muscle satellite cell niche," Cell, vol. 122, no. 2, pp. 289301, 2005.

[95] S. Goudenege, D. F. Pisani, B. Wdziekonski et al., "Enhancement of myogenic and muscle repair capacities of human adipose-derived stem cells with forced expression of MyoD," Molecular Therapy, vol. 17, no. 6, pp. 1064-1072, 2009.

[96] B. Cao, B. Zheng, R. J. Jankowski et al., "Muscle stem cells differentiate into haematopoietic lineages but retain myogenic potential," Nature Cell Biology, vol. 5, no. 7, pp. 640-646, 2003.

[97] Y. Torrente, J. P. Tremblay, F. Pisati et al., "Intraarterial injection of muscle-derived $\mathrm{CD} 34^{+} \mathrm{Sca}-1^{+}$stem cells restores dystrophin in mdx mice," Journal of Cell Biology, vol. 152, no. 2, pp. 335-348, 2001.

[98] E. Bachrach, A. L. Perez, Y. H. Choi et al., "Muscle engraftment of myogenic progenitor cells following intraarterial transplantation," Muscle and Nerve, vol. 34, no. 1, pp. 44-52, 2006.

[99] H. S. Bedair, T. Karthikeyan, A. Quintero, Y. Li, and J. Huard, "Angiotensin II receptor blockade administered after injury improves muscle regeneration and decreases fibrosis in normal skeletal muscle," American Journal of Sports Medicine, vol. 36, no. 8, pp. 1548-1554, 2008.

[100] Z. Qu-Petersen, B. Deasy, R. Jankowski et al., "Identification of a novel population of muscle stem cells in mice: potential for muscle regeneration," Journal of Cell Biology, vol. 157, no. 5, pp. 851-864, 2002.

[101] T. Kinnaird, E. Stabile, M. S. Burnett et al., "Local delivery of marrow-derived stromal cells augments collateral perfusion through paracrine mechanisms," Circulation, vol. 109, no. 12, pp. 1543-1549, 2004.

[102] R. Langer and J. P. Vacanti, "Tissue engineering," Science, vol. 260, no. 5110, pp. 920-926, 1993.

[103] L. A. Hidalgo-Bastida, J. J. A. Barry, N. M. Everitt et al., "Cell adhesion and mechanical properties of a flexible scaffold for cardiac tissue engineering," Acta Biomaterialia, vol. 3, no. 4, pp. 457-462, 2007.

[104] N. F. Huang, S. Patel, R. G. Thakar et al., "Myotube assembly on nanofibrous and micropatterned polymers," Nano Letters, vol. 6, no. 3, pp. 537-542, 2006. 
[105] J. Tan and W. M. Saltzman, "Biomaterials with hierarchically defined micro- and nanoscale structure," Biomaterials, vol. 25, no. 17, pp. 3593-3601, 2004.

[106] R. R. Chen and D. J. Mooney, "Polymeric growth factor delivery strategies for tissue engineering," Pharmaceutical Research, vol. 20, no. 8, pp. 1103-1112, 2003.

[107] L. Y. Qiu and Y. H. Bae, "Polymer architecture and drug delivery," Pharmaceutical Research, vol. 23, no. 1, pp. 1-30, 2006.

[108] Y. C. Huang, K. Riddle, K. G. Rice, and D. J. Mooney, "Long-term in vivo gene expression via delivery of PEI-DNA condensates from porous polymer scaffolds," Human Gene Therapy, vol. 16, no. 5, pp. 609-617, 2005.

[109] E. E. Falco, M. O. Wang, J. A. Thompson et al., "Porous EH and EH-PEG scaffolds as gene delivery vehicles to skeletal muscle," Pharmaceutical Research, vol. 28, no. 6, pp. 13061316, 2011.

[110] A. K. Saxena, J. Makler, M. Benvenuto, G. H. Willital, and J. P. Vacanti, "Skeletal muscle tissue engineering using isolated myoblasts on synthetic biodegradable polymers: preliminary studies," Tissue Engineering, vol. 5, no. 6, pp. 525-531, 1999.

[111] V. Kroehne, I. Heschel, F. Schügner, D. Lasrich, J. W. Bartsch, and H. Jockusch, "Use of a novel collagen matrix with oriented pore structure for muscle cell differentiation in cell culture and in grafts," Journal of Cellular and Molecular Medicine, vol. 12, no. 5A, pp. 1640-1648, 2008.

[112] W. Yan, S. George, U. Fotadar et al., "Tissue engineering of skeletal muscle,” Tissue Engineering, vol. 13, no. 11, pp. 27812790, 2007.

[113] J. P. Beier, J. Stern-Straeter, V. T. Foerster, U. Kneser, G. B. Stark, and A. D. Bach, "Tissue engineering of injectable muscle: three-dimensional myoblast-fibrin injection in the syngeneic rat animal model," Plastic and Reconstructive Surgery, vol. 118, no. 5, pp. 1113-1121, 2006.

[114] T. Matsumoto, J. I. Sasaki, E. Alsberg, H. Egusa, H. Yatani, and T. Sohmura, "Three-dimensional cell and tissue patterning in a strained fibrin gel system," PLoS One, vol. 2, no. 11, Article ID e1211, 2007.

[115] J. Stern-Straeter, A. D. Bach, L. Stangenberg et al., "Impact of electrical stimulation on three-dimensional myoblast cultures-a real-time RT-PCR study," Journal of Cellular and Molecular Medicine, vol. 9, no. 4, pp. 883-892, 2005.

[116] R. L. Page, C. M. Malcuit, L. Vilner et al., "Restoration of skeletal muscle defects with adult human cells delivered on fibrin microthreads," Tissue Engineering Part A. In press.

[117] C. A. Rossi, M. Flaibani, B. Blaauw et al., "In vivo tissue engineering of functional skeletal muscle by freshly isolated satellite cells embedded in a photopolymerizable hydrogel," FASEB Journal, vol. 25, no. 7, pp. 2296-2304, 2011.

[118] G. H. Borschel, R. G. Dennis, and W. M. Kuzon Jr., "Contractile skeletal muscle tissue-engineered on an acellular scaffold," Plastic and Reconstructive Surgery, vol. 113, no. 2, pp. 595-602, 2004. 

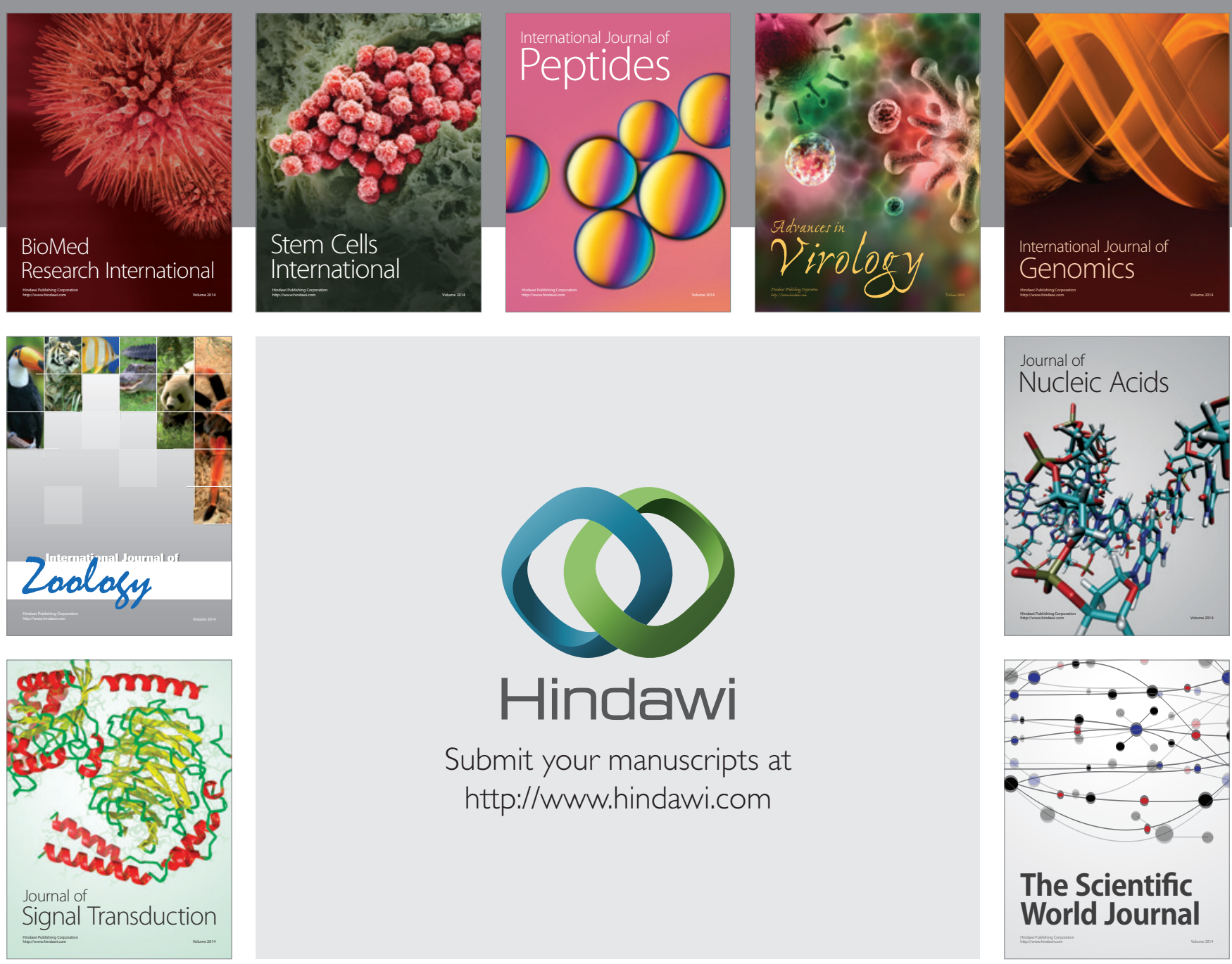

Submit your manuscripts at

http://www.hindawi.com
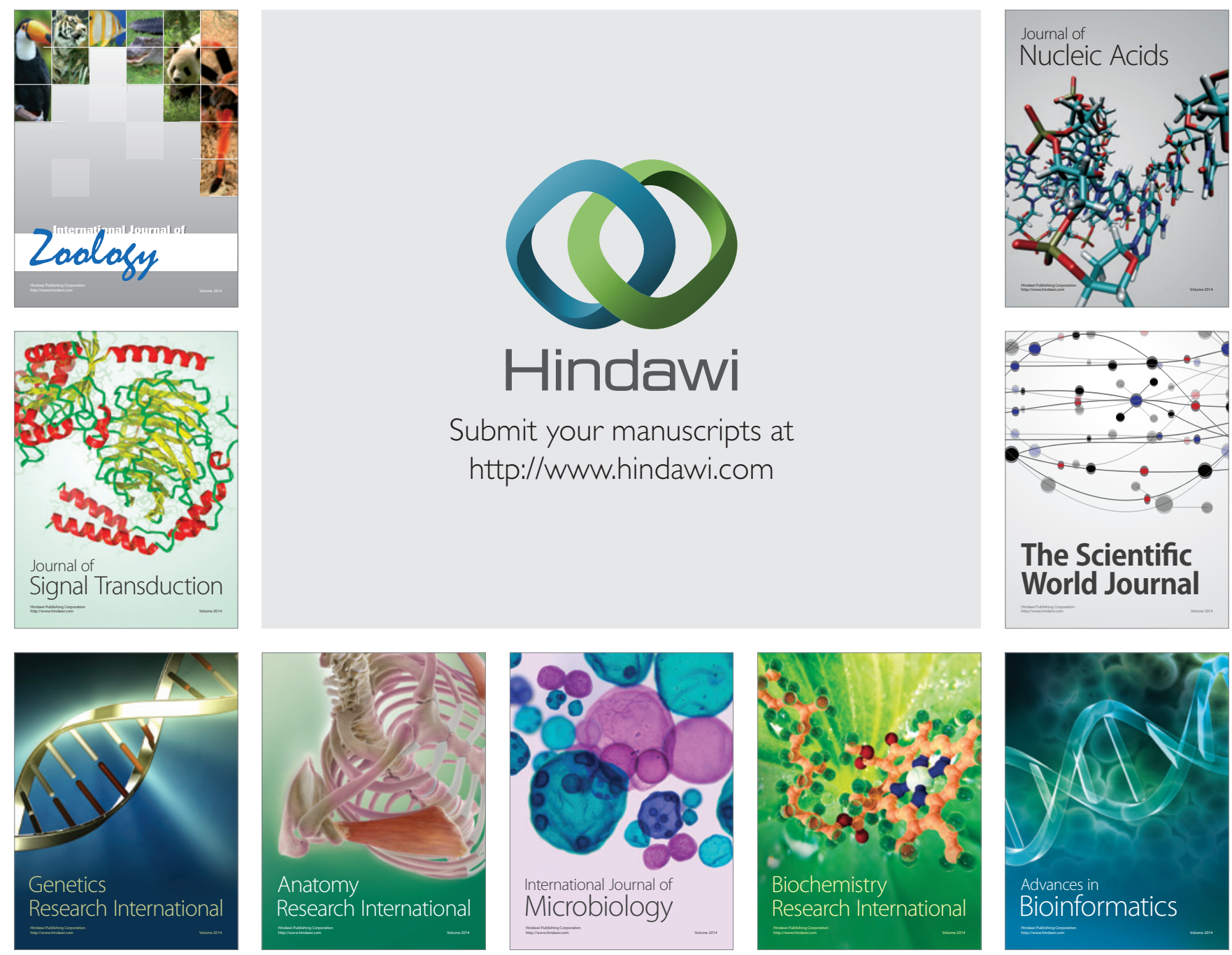

The Scientific World Journal
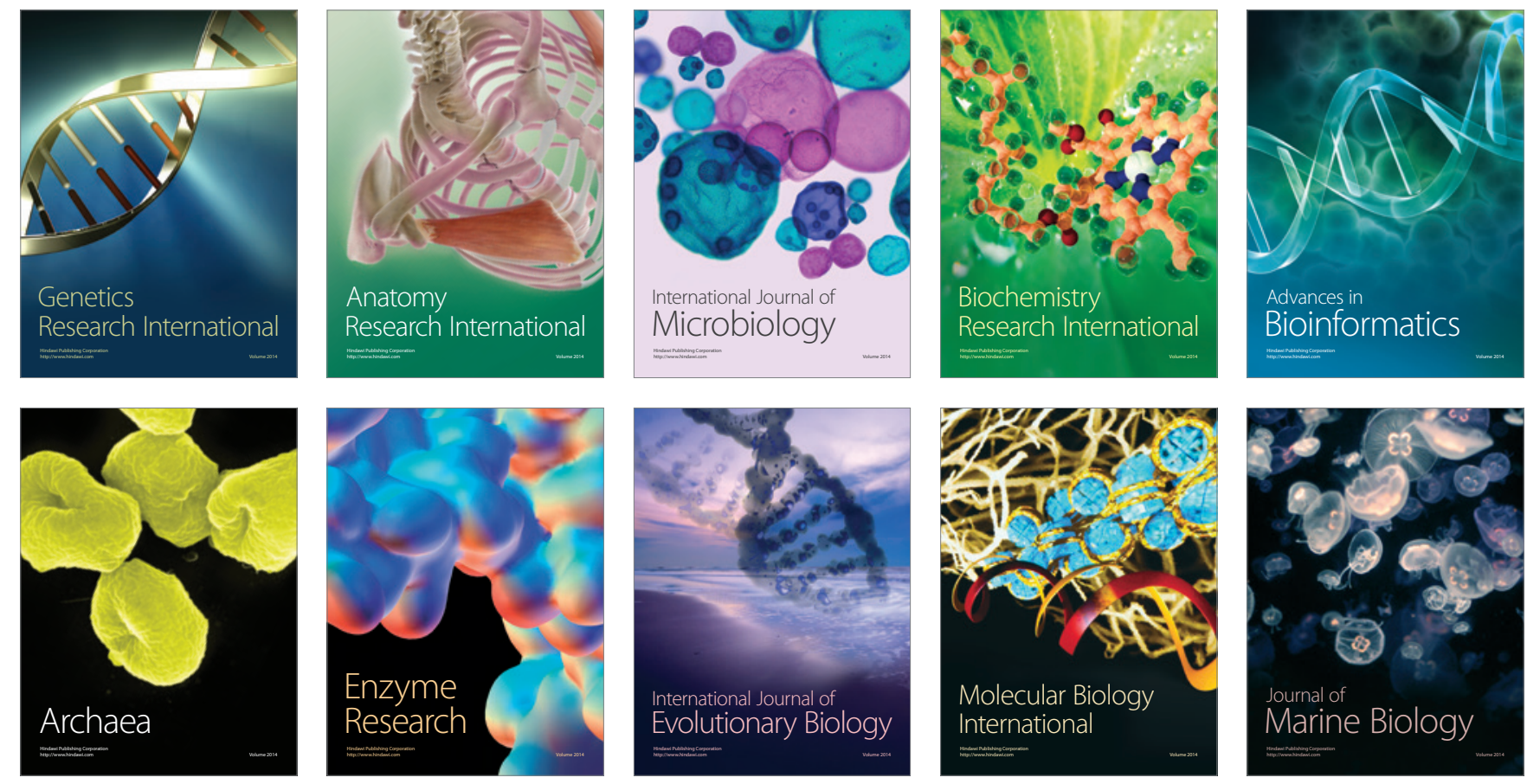